\title{
SOCIAL PARTNERSHIP AS AN IMPORTANT TOOL FOR IMPROVING STUDENT TRAINING
}

\author{
Andriy Zinchenko ${ }^{1}$, Iryna Serohina ${ }^{2}$ \\ ${ }^{1}$ Graduate student at the Department of Pedagogy and Methods of Technological Education, Kryvyi Rih \\ State Pedagogical University, Kryvyi Rih, Ukraine, e-mail: svzi@ukr.net, ORCID: https://orcid.org/0000- \\ 0002-5369-7329 \\ ${ }^{2}$ Ph.D. (Pedagogical Sciences), Associate Professor at the Department of Pedagogy and Methods of \\ Technological Education, Kryvyi Rih State Pedagogical University, Kryvyi Rih, Ukraine, e-mail: \\ irinaseryogina73@gmail.com, ORCID: https://orcid.org/0000-0001-8990-0694
}

Abstract. This article shows the long-term experience of social partnership of Nikopol Vocational College of the National Metallurgical Academy of Ukraine with basic enterprises of Nikopol region as an important tool for improving student training, provides organizational characteristics of social partnership. The purpose of the article is a theoretical analysis of research on the training of university students on the basis of social partnership as a pedagogical problem, an experimental test of the management of the training system of students in accordance with modern requirements of employers. The article presents an analysis of a number of theoretical works of national scientists devoted to the study of the problem of social partnership in universities of I-II level of accreditation with basic enterprises. Particular attention is paid to the basic pedagogical conditions, the readiness of students for training, in order to implement their best knowledge successfully and qualities on the basis of social partnership. The analysis of scientific works revealed the following weaknesses: at the level of universities: insufficient material and technical base; insufficient response to changes in demand for graduates; staff low salaries; at the level of the higher education system as a whole: lack of a unified system (school - college university); in the system of relations "universities - employers": low level of personnel services of enterprises, unresolved issues of retraining. Areas of adjustment of professional training, based on social partnership, which promote professional self-realization and career growth of university graduates have been identified.

Keywords. Social partnership, training, competitiveness, employment, career growth.

JEL Classification: JEL I0; I20

Formulas: 0; fig.: 1, tabl.: 3; bibl.: 16

Introduction. In the conditions of market economy development in Ukraine and fierce competition between the enterprises-manufacturers of metallurgical production, the problem of qualitative professional training of students of high schools according to a modern level of management becomes actual.

The development of the social partnership system creates an opportunity to achieve a relative balance of interests of employers and students of educational institutions on the basis of cooperation.

Now it is especially important to address the new and positive in social partnership, which allows to regulate successfully the training of students, raise the quality and efficiency of educational content, provide a modern level of training graduates of metallurgical specialties, to meet the needs of basic enterprises in highly qualified personnel.

The issue of professional training of university students on the basis of social partnership is an important pedagogical problem that requires detailed theoretical analysis and practical research. 
Literature review. According to the analysis of scientific works of national and foreign scientists (N.H. Didenko, V.I. Pavlova, A.O. Molchanova, A.I. Kudryachenko, etc.), which reveal the essence of the concept "social partnership", which promotes economic stability and development, the creation of a competitive education system of each country, is an important prerequisite for the formation of competitive professionals [1, 2, 3, 4]. In relation to the system of higher education, the urgency of this problem is expressed in the fact that there are contradictions between the quality of training of competitive professionals and modern production needs. In particular, according to many researchers, the quality of professional training of university students does not always meet these needs (S.V. Bezvukha, K. Chugaeva, N.L. Vinogradova, etc.) [5.6.7], identified the main directions and strategies for the development of social partnership in higher education (I.M. Dubrovsky, N.E. Trotsenko, etc.) [8.9]. Some aspects of social partnership of higher education institutions of the I - II level of accreditation are covered in works on the theory of management of professional training and development of personnel (S. Ukrainets, V.I. Zhukova, etc.) [10, 11].

The analysis of theoretical works has shown that the problem of social partnership of universities of I-II years and basic enterprises as an important tool for improving the professional training of students, in ensuring the quality of graduate training, is quite acute. These circumstances make a theoretical and experimental study of the problem of social partnership of universities of I-II accreditation level and employers in improving training is extremely relevant.

Regarding our subject of research, we consider it necessary to note that the main pedagogical conditions in training on the basis of social partnership include: the organization of the educational and production process, which guarantees the training of competitive professionals; choice of educational strategy, taking into account trends in the labor market and professionals; development of new means of motivation and stimulation of educational and cognitive activity of students; formation of their lifelong learning needs; creation and development of the mechanism of self-development.

Aims. The purpose of the article is a theoretical analysis of research on the training of university students on the basis of social partnership as a pedagogical problem, an experimental test of the management of the training system of students in accordance with modern requirements of employers.

Methods. The sources of research are the works of foreign scholars on social partnership. The results of a study on the social partnership between education and business to improve the training of students are presented. The focus is on innovation in the use of social partnership for educational purposes. The article uses statistical and graphical methods, expert method, analysis and synthesis to achieve the goal of the study.

Results. In our time of economic development of Ukraine, the work of state authorities is aimed at decentralization, Nikopol Vocational College NMetAU, which is part of NMetAU, and basic mining and metallurgical enterprises of Nikopol region has concluded long-term tripartite agreements (NVC NMetAU, basic social 
enterprises, UN partnership for 2012 - 2022, the main purpose of which is the real practical training of students at the basic metallurgical enterprises of the Nikopol region for the possibility of their further employment and social protection.

Social partnership, establishment and strengthening of connections with the basic enterprises of the city of Nikopol open for Nikopol professional college of NMetAU additional opportunities of advanced development:

- NFC NMetAU together with employers develop (agree) curricula and programs for vocational training of junior specialists, including curricula and programs for the study of new technology, modern production technologies of enterprises, students' work during internships on new equipment;

- involve leading teachers of special disciplines of the professional college to work in technical meetings of enterprises, in order to use production indicators and the level of technical equipment of the enterprise in students' diploma projects. Provide an opportunity for internships for teachers of special disciplines at employers' enterprises;

- carry out a constant exchange of information between partners by holding conferences, meetings of methodical councils "Enterprise - College";

- provide internships for students, training for students' working professions, employment of graduates of vocational colleges and their adaptation in the workplace;

- enterprises participate in material and technical support, strengthening the educational and laboratory base of the professional college;

- created at the NFC NMetAU Practice Department (Alumni Liaison Council, Employers' Club, Career Support and Employment Center);

- real diploma projects of students are developed at the request of enterprises. Enterprises provide materials and tasks for students to prepare real diploma projects and research papers;

- participation in the preparation and holding of joint events (scientific and practical conferences, welcoming evenings, questionnaires, making booklets, etc.). The main principle of social partnership is the principle of joint activity of Nikopol Vocational College NMetAU and employers, which provides activity, equality of the parties, compliance with the law, voluntariness and responsibility in accepting obligations, constant consultative interaction, positive acceptance of each other, open space of social partnership.

The main principle of social partnership is the principle of joint activity of Nikopol Vocational College NMetAU and employers, which provides activity, equality of the parties, and compliance with the law, voluntariness and responsibility in making commitments, constant consultation, positive acceptance of each other, open space of social partnership.

Tasks of social partnership:

1. Development and implementation of educational policy of Nikopol Vocational College of the National Metallurgical Academy of Ukraine, which takes into account the interests of student personality development. 
2. Correction of the content of technologies of professional and practical training of junior specialists of Nikopol Vocational College of NMetAU.

3. Improving the quality of vocational training, education of graduates, competitiveness in the labor market, development of measures for its social protection

Social partnership is aimed at implementing the requirements of basic enterprises in the Nikopol region:

1. Professional training of a competitive graduate;

2. Raising the level of general and professional culture of graduates;

3. Formation of conscious motivation to work;

4. Development of skills of entrepreneurial and organizational activity.

The main purpose of the social partnership is to coordinate the actions of the parties to organize and conduct professional training (retraining and advanced training) of graduates taking into account the requirements of production, development of necessary educational documentation, methodological and other materials, updating material and technical and laboratory facilities.

The program of social partnership of Nikopol Vocational College and basic enterprises for 2012-2022 is designed to ensure the current level of professional training of graduates, improve the material and technical base of the educational process, the organization of industrial practice and employment.

The social partnership program includes:

- joint actions for the organization and conduct of production practice;

- internship of students with payment;

- further employment of graduates;

- involvement of leading production specialists in qualification commissions for the defense of diploma projects;

- holding joint city events, conferences, round tables, etc .;

- material encouragement of the best teachers - practice leaders;

- improving the material base of the vocational college;

- development of the necessary educational and methodical documentation.

The main task of the Social Partnership Program is employment, social protection of graduates and teachers of the vocational college.

The main areas of work of the department of industrial practice:

1. organization of internships at enterprises ( $100 \%$ with remuneration), with subsequent employment;

2. distribution of students to enterprises according to the rating;

3. annual competitions "Best in the specialty", Career Days together with representatives of enterprises;

4. conducting thematic excursions in the specialty to the basic enterprises of Dnipropetrovsk and Zaporizhia regions;

5. obtaining a related working profession (smelter, non-destructive testing inspector) for the purpose of further employment;

6. conducting "Master Classes" to study the specifics of production technology. In our opinion, the need to implement a social partnership between the Nikopol 
Vocational College and the basic enterprises of the Nikopol region was experimentally confirmed in order to combine educational activities with the professional and training of competitive professionals.

We believe that the studied features of professional training of students on the basis of social partnership can be divided into stages:

- initial stage, professional self-determination;

- professional adaptation in the conditions of study in high school, I - II course;

- stage of specialization, third year;

- practical stage of adaptation (preparation for the future specialty in the conditions of production), IV course;

- stage of employment, adaptation to the labor market.

In order to implement professional training, a set of activities was held on the basis of social partnership (coordination of programs and plans of special disciplines and practices, holding scientific and practical conferences, competitions in special disciplines, use of modern information technologies, modern computer programs, "Master Classes" with leading experts).

At the initial stage of professional training of students, psychological trainings, career guidance festivals, welcoming evenings, thematic excursions to basic enterprises and others were conducted.

At the stage of specialization, research work was organized, students participated in additional educational programs (foreign language, energy management, etc.).

The main task of professional training at the practical stage is the participation of students in scientific work, obtaining related specialties, work in production by profession. To this end, production plans have been adjusted using multimedia computer-based learning technologies.

At the stage of employment there is a conscious choice of professional activity and place of work. In this regard, a number of events are held (job fair, meetings with leading specialists of basic enterprises, etc.).

According to the results of the annual survey among graduates, the main characteristics of the quality of professional training of graduates of NFC NMetAU (theoretical and professional competence, ability to use modern computer technology, knowledge of a foreign language, level of general professional culture, etc.) were identified. These questionnaires allow us to analyze the role of professional training of university graduates and make the necessary adjustments.

The results of expert evaluation, surveys, questionnaires of employers, teachers, graduates, positive dynamics of professional and personal qualities of a professional college student confirm the effectiveness and pedagogical purpose of professional training of competitive graduates on the basis of social partnership, raising the image of higher education.

The graduates of Nikopol Vocational College were monitored by "Your professional plans after graduation from vocational college." According to the results of the survey in 2019-2020 academic year: 63\% of graduates are employed at enterprises, of which they simultaneously study at NF NMetAU - 31.88\%; will not 
work on the received education - $19.4 \%$; will go to work in another country $-6.9 \%$; undecided $-10.7 \%$.

\section{Table 1. Professional plans of graduates of Nikopol Vocational College of the National Metallurgical Academy of Ukraine after graduation}

\begin{tabular}{|l|l|l|l|}
\hline \multicolumn{1}{|l|}{ What are your professional plans after graduating from college? } & $\begin{array}{c}2017- \\
2018\end{array}$ & $\begin{array}{c}2018- \\
2019\end{array}$ & $\begin{array}{c}2019- \\
2020\end{array}$ \\
\hline $\begin{array}{l}\text { I know that I will work in practice in the specialty with further } \\
\text { employment at the company. }\end{array}$ & 70 & 60 & 63 \\
\hline I know that I will not work on my education & 18 & 19,7 & 19,4 \\
\hline I will go to work in another city / country & 7 & 6,1 & 6,9 \\
\hline Not yet decide & 5 & 14,2 & 11,7 \\
\hline
\end{tabular}

The plans of Vocational College students for further study present by Table 2.

Table 2. Plans of Vocational College students for further study, $\%$

\begin{tabular}{|l|l|l|}
\hline & $\mathbf{2 0 1 8} / \mathbf{2 0 1 9}$ & $\mathbf{2 0 1 9 / 2 0 2 0}$ \\
\hline Continuation of studies at NMetAU & $\mathbf{3 1 , 8 8}$ & $\mathbf{3 5}$ \\
\hline Continuation of studies in universities of Ukraine & 10,94 & 25 \\
\hline Continuation of studies in universities of another country & 7,19 & 10 \\
\hline Difficult to answer & 30,47 & 5 \\
\hline No answer & 19,52 & 5 \\
\hline
\end{tabular}

Discussions. In our opinion, the social partnership of universities and basic enterprises as a regulator of professional training can be divided into 4 stages:

1. Familiarization and design stage (1-2 course):

1.1 educational institution: acquaintance with new conditions of study, definition of final knowledge, with requirements of teachers, with rules and duties of the student, carrying out of additional employment and electives on fundamental disciplines, studying of modern computer technologies, carrying out questionnaires and testing;

1.2 basic enterprises: participation in the material and technical support of the educational institution, conducting thematic excursions to basic enterprises, meetings with labor veterans.

Table 3. Comparative table of employment

\begin{tabular}{|l|c|c|c|c|c|c|c|c|c|c|}
\hline \multicolumn{1}{|c|}{ Indicators } & \multicolumn{7}{|c|}{ 2011-2020 in-period information } \\
\cline { 2 - 11 } & 2011 & 2012 & 2013 & 2014 & 2015 & 2016 & 2017 & 2018 & 2019 & 2020 \\
\hline $\begin{array}{l}\text { Number of graduates of the } \\
\text { educational institution, persons }\end{array}$ & 230 & 197 & 141 & 210 & 170 & 170 & 191 & 123 & 123 & 104 \\
\hline $\begin{array}{l}\text { Number of employed } \\
\text { graduates of the educational } \\
\text { institution, as young } \\
\text { employees, persons }\end{array}$ & 123 & 125 & 110 & 120 & 97 & 110 & 120 & 110 & 108 & 95 \\
\hline $\begin{array}{l}\text { Number of concluded } \\
\text { agreements between the } \\
\text { employer and the person } \\
\text { continuing training, units - } \\
\text { total }\end{array}$ & 45 & 41 & 39 & 40 & 40 & 40 & 40 & 30 & 28 & 25 \\
\hline
\end{tabular}


2. The main stage (corrective) (2-3 course):

2.1 educational institution: study of special disciplines, organization of professional activity of students in the form of metalwork and mechanical practice, participation in research work, competitions, scientific and practical conferences, correction of educational and production process, finding out the causes of errors and ways to eliminate them ;

2.2 basic enterprises: participation in scientific and practical seminars, meetings with managers and leading specialists of enterprises conducting thematic excursions to basic enterprises.

3. Final (control) stage (4th year):

3.1 educational institution: control of dynamics of development of professional adaptation of students; implementation of real course and diploma projects, conducting master classes, writing research papers on the future specialty, internships at basic enterprises with further employment, participation in joint activities with enterprises;

3.2 basic enterprises: conducting qualification examinations for the provision of working categories, participation in qualification commissions, providing recommendations to the best students for higher education III - IV academic year. at the expense of the enterprise.

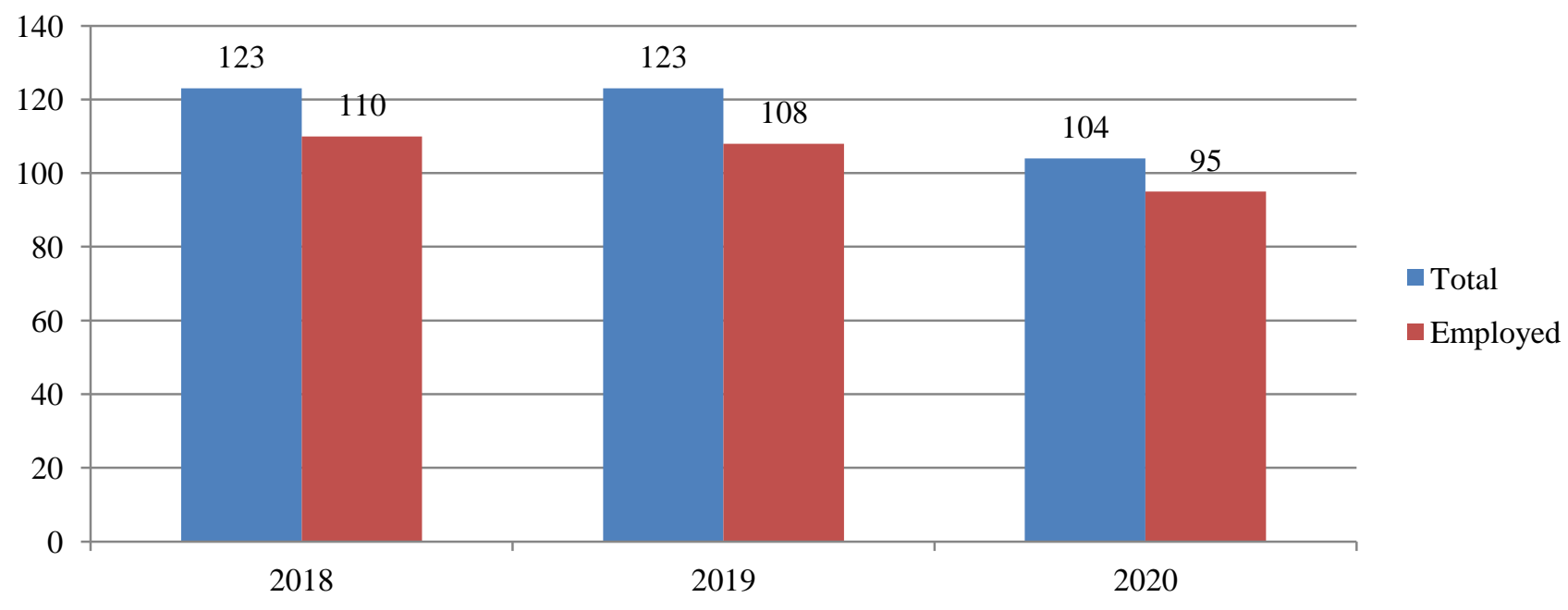

Figure 1. Employment of graduates

Conclusions. Thus, the need for the implementation of social partnership of universities with basic enterprises as an important tool for improving the training of competitive graduates was experimentally confirmed.

The set of conditions that ensure the effectiveness of social partnership, the quality of professional training of university students in accordance with modern requirements of employers is defined and substantiated.

The experience of the Nikopol Vocational College of NMetAU with the basic enterprises of the Nikopol region in the implementation of professional training of university students on the basis of social partnership shows that it is possible to cooperate with employers really and effectively.

Author contributions. The authors contributed equally. 


\section{Disclosure statement. The authors do not have any conflict of interest. References:}

1. Didenko, N.H. (2007), Derzhavne upravlinnia i sotsialne partnerstvo: aktualni problemy teorii i praktyky : monohrafiia. [Public administration and social partnership: current issues of theory and practice: a monograph], Donetsk: Skhidnyi vydavnychyi dim [in Ukrainian].

2. Pavlov, V.I., Kolosok, A.M. Sotsialne (2009), Partnerstvo na rynku pratsi Ukrainy: monohrafiia. [Social partnership in the labor market of Ukraine: a monograph], Rivne: NUVHP [in Ukrainian].

3. Molchanova, A.O. (2007), Sotsialne partnerstvo v diialnosti PTNZ: Konspekt lektsii [Social partnership in the activities of vocational schools: Lecture notes]. Kyiv: TOK [in Ukrainian].

4. Kudriachenko, A.I. (2008), Sotsialne partnerstvo: yevropeiskyi dosvid i Ukraina. [Social partnership: European experience and Ukraine] Stratehichni priorytety, 3(8), 132 - 141 [in Ukrainian].

5. Bezvukh, S.V., Stopchak, A.Iu. (2015), Sotsialne partnerstvo nauky i biznesu: formy vzaiemodii problemy i rekomendatsii shchodo yikh vyrishennia. [Social partnership of science and business: forms of interaction of the problem and recommendations for their solution]. Visnyk Khmelnytskoho natsionalnoho universytetu. Ekonomichni nauky, 3(3), 7-14 [in Ukrainian].

6. Chugaev, K.A. (2004), Obespecheniye kachestva professionalnogo obrazovaniya $\mathrm{v}$ usloviyakh sotsialnogo dialoga. [Ensuring the quality of vocational education in the context of social dialogue]. Professionalnoye obrazovaniye, 9, 25-26 [in Russian].

7. Vinogradova, N.L. (2005), Sotsialnoye prostranstvo i sotsialnoye vzayemodeystviye. [Social space and social interaction.] Vestnik VGU. Seriya Gumanitarnyye nauki, 2, 39 - 54. [in Russian].

8. Dubrovskyi, I.M. (2009), Systema sotsialnoho partnerstva yak rehuliator sotsialno-trudovykh vidnosyn $\mathrm{v}$ umovakh transformatsii ukrainskoho suspilstva (sotsiolohichnyi analiz) [The system of social partnership as a regulator of social and labor relations in the transformation of Ukrainian society (sociological analysis)] Kharkiv: National University of Kharkiv [in Ukrainian].

9. Trotsenko, N.Ye. (2011), Sotsialne partnerstvo yak odna z pedahohichnykh umov profesiinoho samovdoskonalennia sotsialnykh pratsivnykiv u resursnykh tsentrakh. [Social partnership as one of the pedagogical conditions for professional self-improvement of social workers in resource centers] Visnyk Zaporizkoho natsionalnoho universytetu, 3(16), 169-174. [in Ukrainian].

10. Ukrainets, S. (1998), Sotsialne partnerstvo v Ukraini : perspektyvy zakonodavchoho rehuliuvannia [Social partnership in Ukraine: prospects of legislative regulation.]. Ukraina : aspekty pratsi, 2, 22-25 [in Ukrainian].

11. Zhukov, V.I., Skurativskyi, V.A. (2000), Sotsialne partnerstvo v Ukraini. Navchalnyi posibnyk. [Social partnership in Ukraine. Textbook]. Kyiv: UADU [in Ukrainian].

12. Zinchenko, S.M. (2014), Sotsialne partnerstvo NT NMetAU z bazovymy pidpryiemstvamy m. Nikopolia v 2004-2014 rokakh: chas vyprobuvan, chas poshuku, chas novykh dosiahnen. Nikopol [in Ukrainian].

13. Zinchenko, A.L. (2019), Profesiina pidhotovka vypusknykiv do orhanizatsii sotsialnoho partnerstva v sferi suspilnoho vyrobnytstva: Yevropeiskyi dosvid.[ Professional preparation of graduates for the organization of social partnership in the field of social production: European experience.] Naukovi zapysky Seriia: Pedahohichni nauky, 182, 205 - 211 [in Ukrainian].

14. Zinchenko, A.L., Zinchenko, S.M. (2013) Zbirnyk metodychnykh rekomendatsii «Sotsialne partnerstvo $\mathrm{z}$ bazovymy pidpryiemstvamy $\mathrm{m}$. Nikopol» [Collection of methodical recommendations «Social partnership with basic enterprises of Nikopol»]. Nikopol [in Ukrainian].

15. Zinchenko, S., Savchenko, G., Stupak, Y., Bobkova, L., (2018) Feedback with emloyers as an effective tool for improving the training of specialists in the university. Kharkiv: Mizhnar. konf. "Aktualni pytannia osvity i nauky", [in English].

16. Halchenko, H., Kuzmina, O. (2013) Rol pidpryiemstva v navchalnomu protsesi. Praktyka yevropeiskykh universytetiv [The role of the enterprise in the educational process. Practice of European universities]. Dnipro: Vydavnytstvo «Driant» [in Ukrainian]. 